\title{
Editorial - Volume 37, Issue 3
}

\author{
Peta J. White
}

AJEE Editor-In-Chief

\section{Heralding Change in the Editorial Executive of AJEE}

Welcome to the third and final issue (\#3) of Volume 37. This issue heralds significant change in AJEE Editorial Executive and the start of the journal moving to four issues per year. We have had a very exciting year and are pleased share our news.

At the October 2021 Australian Association of Environmental Education (AAEE) AGM, our Editor-In-Chief, Amy Cutter Mackenzie Knowles 'passed the baton'. We emphatically thank Amy for her 11 years of leadership and voluntary service to AJEE and our community.

We asked Amy to reminisce with us so that we could honour her service to AJEE, here is what she said: Amy started as the AJEE Editor in 2010, taking over from Jo Ferreira. At that time there was a notice placed in the OzEE News inviting expressions of interest for the AJEE Editor role, Amy replied and started asap. As Editor, Amy did everything from supporting authors to submit and develop their manuscripts, to preparing each annual issue and arranging the publication. She managed all aspects of production as the journal was published 'in-house' by AAEE.

To grow the journal and ensure its survival, Amy worked with the then AAEE President Phil Smith to negotiate an academic publishing contract for the journal. They courted Springer and Taylor and Francis, before confirming an agreement with the Australian Academic Press. The journal blossomed and grew with Amy at the helm. This publishing company was then sold to Cambridge University Press, launching AJEE as an international journal. This important transition ensured the journal's evolution to the strong position it now holds in the field of environmental education, with Amy taking the role of Editor-In-Chief. In 2011, AJEE moved to two issues per year, in 2016 to three issues, and now in 2022 the journal will move to four issues per year.

Amy remembers many interesting manuscripts and anecdotes from her editorial experiences, and she has promised to curate a retrospective for us, focussing on the most impactful articles she edited to publication. Look for this soon the on the AJEE site (https://www.cambridge.org/core/journals/australian-journal-of-environmental-education). Amy noted two manuscripts that were highlights ...

"The article by Alistair Stewart (2011) was one of the most memorable as it speaks beautifully to pedagogy and theory through becoming-animal. It is still highly relevant as humans grapple with their own animality on a multispecies planet;" and

"The article by Blanche Verlie, Emily Clark, Tamara Jarrett, and Emma Supriyono (2021) on educators' experiences and strategies for responding to ecological distress. It's apt in this moment of climate peril, and yet reinvigorating to see a new generation of environmental education researchers."

A key moment in the history of the AJEE saw Amy collaborate with Annette Gough, Noel Gough, and Hilary Whitehouse to deliver a special 30-year Anniversary issue (Volume 30 Issue 1 - 2014). This editorial framed the history of AJEE and named the most significant articles previously published in the journal judged against three core criteria:

- Research impact, quality, and scholarship. These measures were based on citations and peer review criteria similar to those deployed by the Excellence for Research in Australia (ERA) initiative; 
- Relevance in 2014 (especially for early career and aspiring researchers); and

- Appeal to the AAEE membership.

The editors invited the authors to provide a short response to the original article. What an exciting and relevant way for AJEE to turn 30.

As the AJEE Editor-In-Chief, Amy enjoyed working with authors as they developed their manuscripts to readiness for publication, often across several iterations and sometimes years. Amy developed an international AJEE Editorial Board, one that currently includes 33 of the top researchers in the field. She increased the opportunity for special issues, inviting guest editors to create focussed issues around innovative themes, often providing exciting opportunities for early career researchers. These curated issues are wonderful for researchers to mine for contemporary research. And from 2012 Amy grew the Editorial Executive of AJEE. She invited me to take on the role of Book Review Editor and in 2015 Chris Eames as an Associate Editor. This growth continued and in 2021, the Editorial Executive is currently a healthy community of eight academic volunteers.

It is this team of eight who will be moving AJEE forward into the bright new world with the shift to publishing four issues a year with volume 38 (in 2022), hosting curated retrospectives, introducing video abstracts, social media engagement, and more. I am pleased to be stepping into the Editor-In-Chief role, and I will introduce you to the ongoing AJEE Editorial Executive.

Before we do that, however, we owe one more round of applause to Chris Eames as he is also stepping off the Editorial Executive to join the Editorial Board. Chris joined the AJEE Editorial Executive as the inaugural Associate Editor in 2015. In this role he assigned reviewers for incoming articles, considered these reviews when they were returned, and provided feedback to the Editor-In-Chief for passing on to the author(s). He also supported Amy (EditorIn-Chief) in decisions around policy and procedures, making the journal a success.

Chris considers a favourite manuscript as "Ngā Waihotanga Iho: Self-determination through indigenous environmental education in New Zealand" by Dodson and Miru (2021 - published in this issue) although he notes his possible bias in this choice because it is focussed on New Zealand. This article addresses the important issue of Indigenous education and the carefully selected reviewers gave thoughtful and useful feedback.

Chris's demonstrated commitment to the voluntary role of AJEE Associate Editor is clear: he managed 102 manuscripts as part of his service. He noted that his greatest pleasure was the opportunity to support many authors to bring their manuscripts to the highest quality for publication. Chris has fond memories of one group of authors who were very grateful for the constructive feedback and delighted when their article was published. He also remembers an article that he and the reviewers worked on for 18 months through 4 iterations to help an author raise the quality of the research representation. The manuscript didn't proceed to publication, and the moral of this story is that while we go to some extraordinary lengths to support authors, we all share the disappointment when publication success is not the result of all the effort. We share in the belief that AJEE provides quality contributions to the field with mentoring and support along the way.

So, from the bottom of our hearts, we thank you Amy and Chris. Your voluntary hours of service, mentoring, and leadership in the research field are greatly appreciated, and you have generated a wonderful AJEE community. We are pleased to now welcome you both to the AJEE Editorial Board and look forward to your continued support of AJEE.

\section{Moving Forward}

It is with great pleasure that I now introduce you to the new AJEE Editorial Executive

Editor-In-Chief - Peta J. White, Senior Lecturer in Environmental and Science Education, School of education, Deakin University, Australia. https://www.deakin.edu.au/about-deakin/ people/peta-white 
Associate Editor - Hilary Whitehouse, Deputy Dean, Graduate Research, James Cook University, Australia. https://research.jcu.edu.au/portfolio/hilary.whitehouse

Associate Editor - Sandra Wooltorton, Senior Research Fellow, Nulungu Research Centre, Notre Dame University, Australia. https://www.notredame.edu.au/research/nulungu/staff/ sandra-wooltorton

Associate Editor - Blanche Verlie, Postdoctoral Fellow, Sydney Environment Institute, University of Sydney, Australia. https://www.sydney.edu.au/arts/about/our-people/academicstaff/blanche-verlie.html

Associate Editor - Marianne Logan, Associate Director of Higher Degree Research, School of Education, Southern Cross University, Australia. https://www.scu.edu.au/about/contacts/staffdirectory/staff/28261.php

Book Review Editor -Joseph Ferguson, Postdoctoral Fellow, School of Education, Deakin University, Australia. https://www.deakin.edu.au/about-deakin/people/joe-ferguson

Thesis Synopsis Editor - Kathryn Riley, Postdoctoral Fellow, University of Saskatchewan, Canada. https://www.linkedin.com/in/dr-kathryn-riley

Editorial Assistant - Jorja McKinnon, $\mathrm{PhD}$ candidate and casual academic, School of Education, Deakin University, Australia. https://www.deakin.edu.au/about-deakin/people/jorjamckinnon

The Editorial Executive is supported by Cambridge University Press alongside the AJEE Editorial Board, renewed in 2020 (2020-2024). A complete listing of the Editorial Board is available at https://www.cambridge.org/core/journals/australian-journal-of-environmental-education/ information/editorial-board.

The Editorial Executive is a team of eight, who are excited to take AJEE forward and have plans to develop our editor, author, reviewer, and reader experience and to increase the citations and impact of AJEE. We continue to work towards moving AJEE to Q1, and we look forward to showcasing two special issues next year - Volume 38:

1. Striking from School for the Climate. Guest Editors: Blanche Verlie and Alicia Flynn

2. Post-Qualitative Inquiry: Theory and Practice in Environmental Education. Guest Editors: Paul Hart and Peta White.

\section{This Issue}

In this issue AJEE offers a range of papers that exemplify our diverse and lively field highlighting some of our contemporary researchers. We include two book reviews:

- Sarah Jaquette Ray (2020). A Field Guide to Climate Anxiety: How to Keep your Cool on a Warming Planet, University of California Press.

- Heila Lotz-Sisitka, Overson Shumba, Justin Lupele and Di Wilmot (Eds) (2017). Schooling for Sustainable Development in Africa. Springer

Exploring children's literature related to marine science, the first paper by Prue F. Francis, Paul Venzo, and Alecia Bellgrove, invites us to "read under the waves". Continuing with children's perceptions, Dylan Adams and Gary Beauchamp investigate how playing a hunting game (on location of a nature reserve) enables children to consider other knowing as they experience otherness. Children's understandings of our world is further explored through representations of what an ideal environmental school looks like by Adiv Gal and Dafna Gan.

Güliz Karaarslan Semiz and Zeynep Temiz consider pre-service teachers' perceptions and practices of nature-based teaching in an early childhood context. This research is set in 
Turkey, illustrating the international reach of AJEE. Staying international and with teacher education Laura Sims, Hilary Inwood, Paul Elliott, and Susan Gerofsky illuminate innovative praxis for environmental learning for faculties of education in Canada. Maintaining our higher education focus, from business scholarship, Breda McCarthy and Lynne Eagle research whether the employer needs regarding sustainability-oriented skills and competencies are being met by graduates.

Moving our focus to Ecuador, empathy-based sensitising and knowledge reinforcement in dolphin watching is explored by Ricardo Villalba-Briones, Mariela A. González-Narvaez, and Tomas Vitvar.

We are fortunate to have two papers on plastics which is an increasing and ubiquitous issue in our environments, negatively impacting ecosystems around the world. The plastic waste minimisation intention of Hong Kong citizens is researched by Winnie Wing Mui So, Irene Nga Yee Cheng, Lewis Ting On Cheung, Yu Chen, Stephen Cheuk Fai Chow, Lincoln Fok, and Sing Kai Lo. The factors influencing the use of non-plastic reusable shopping bags is researched by Asphat Muposhi, Mercy Mpinganjira, and Marius Wait.

Finally, we invite you to engage with indigenous environmental education through this important paper by Giles Dodson and Mikaera Miru (the paper Chris Eames mentioned as a favourite) as the authors consider self-determination through Indigenous environmental education in New Zealand.

Congratulations to our volume 37, issue 3 authors, we hope that your experience publishing with AJEE has been enjoyable and also productive. Many thanks to our reviewers, your contribution to this academic work is most appreciated and valued.

Finally, to our readers, we trust you relish these significant offerings and then continue to explore the literature presented in the other 36 volumes of AJEE. We look forward to sharing volume 38 across four issues in 2022.

\section{References}

Cutter-Mackenzie, A., Gough, A., Gough, N., \& Whitehouse, H. (2014). Opening to the Australian Journal of Environmental Education Special 30-Year Anniversary Issue. Australian Journal of Environmental Education, 30(1), v-vi. http://doi.org/10.1017/aee.2014.12

Dodson, G., \& Miru, M. (2021). Ngā Waihotanga Iho: self-determination through Indigenous environmental education in New Zealand. Australian Journal of Environmental Education, 37(3). http://doi.org/10.1017/aee.2021.5

Verlie, B., Clark, E., Jarrett, T., \& Supriyono, E. (2021). Educators' experiences and strategies for responding to ecological distress. Australian Journal of Environmental Education, 37(2), 132-146. http://doi.org/10.1017/aee.2020.34

Stewart, A. (2011). Becoming-speckled warbler: re/creating Australian Natural History Pedagogy. Australian Journal of Environmental Education, 27(1), 68-80. doi: 10.1017/S0814062600000082

Cite this article: White, P.J. (2021). Editorial - Volume 37, Issue 3. Australian Journal of Environmental Education 37, 163-166. https://doi.org/10.1017/aee.2021.26 